\title{
消音器の音響減衰測定方法について \\ ON MEASUREMENT METHODS OF SOUND ATTENUATION OF SILENCERS
}

\author{
板 本 守正*, 㦈川博義**, 奥住 滋*** \\ Morimasa ITAMOTO, Hiroyoshi SHIOKA WA \\ and Shigeru OKUZUMI
}

\begin{abstract}
Measurement methods of sound attenuation of silencers are studied to determine data for sound attenuation design of air conditioning systems. Measurement methods of sound attenuation of silencers are standardized in ISO 7235. A large non-reflection termination is needed in this standard. But laboratories with this termination are few in Japan. So in this paper, for suggesting simple and practical measurement methods, several measurement methods ( includes that of IS0 7235) are compared and discussed. A substitution method and a direct method are described. A non-reflection termination based on ISO and that of simple type are used in measurement methods.
\end{abstract}

Keywords : silencer, sound attenuation, insertion loss, substitution method, direct method,

消音器, 音響減衰, 挿入損失, 置換法, 直接法

\section{1. 緒言}

空調設㣁の消音設計において適切な消音器の選定を行 なうためには、その音響隇衰せ11特性が必要である。消 音器の種類によってはある程度予測できるものもあるが、 形状、寸法および内部表面加工などの違いとともにその 特性は大きく異なる。そのため実験により各種消音器の 減衰量を明確にしなけれはならない場合が多い。近年、 空調ダクト系における騒音制御を目的とした各種消音器 の音響減衰特性を明らかにするため、ISO $7235^{1)}$ が制定 され、有風時および無風時における置換法による挿入損 失測定方法が規定されている。

しかし、この規格では大がかりな試験設俌が規定され、 これに対応できる試験機関は日本ではほとんどない。
そこで本報告では、実務上設計データとして必要とな る消音器の音響隇䱏量を简便かつ実用的に求める測定方 法を提案するために、ISO規格の测定方法を含め、いく つかの測定方法および装置を設定し、各種測定方法およ び装固の違いによる減衰量を比較検討する。

\section{2. 供試体}

供試体を図1に示す。スプリッタ型消音器の直管部お よび曲管部について剆定を行なう。外板は建設省基準の 厚さより 1 番手厚い重鉛鉄板を用い、吸音体は多孔亜鈆 鉄板 $(\mathrm{t}=0.6 \mathrm{~mm})$ 内にグラスウール $\left(\right.$ 比重 $\left.24 \mathrm{~kg} / \mathrm{m}^{3}\right)$ を充填し ている。また、自由面積比は $42 \%$ である。

\footnotetext{
本論文は日本建築学会大会において発表した文献2)の内容を再検討し，まとめ直したものである。

* 日本大学生産工学部建築工学科 教授.工博 Prof., Dept. of Architectural Engineering, College of Industrial

Technology, Nihon Univ., Dr. Eng.

** 日本大学生産工学部建築工学科 専任講師 · Lecturer, Dept. of Architectural Engineering, College of Industrial 工博

*** 日本大学生産工学部建築工学科 副手

Technology, Nihon Univ., Dr. Eng.

Research Assoc., Dept. of Architectural Engineering, College of Industrial Technology, Nihon Univ.
} 
3. 無反射端（Non-ref.termination）

剆定には、以下の無反射端 2 種を用いた。

\section{1 ISO無反射端}

IS0 7235 (Annex D Figure D.1 a)）に基づいた無 反射端である。

\section{2 简易無反射端}

供試体と同じ断面を持つ長さ $900 \mathrm{~mm}$ の铁板ダク内に、 グラスウールを充買したものである。なお、湘定ダクト との接続部の反対側は盲フランジにて閉顉する。

\section{3 IS 0 無反射端および简易無反射端の} 音圧反射係数

IS0 7235 (Annex D D.2） に基づき测定により求めた ISO無反射端および简易無反射端の音圧反射係效を表 1 に示す。ISOに規定されている最大音圧反射係效と比辝 すると、IS0無反射端は、各周波数带域において規定値 より小さい値を示す。また、簡易無反射端は、63および $125 \mathrm{~Hz}$ 帯域が規定值より大きい值を示すが、他の各周波 敏带域においては、規定值より小さい値を示す。また、 63 500Hz带域のいずれにおいても、ISO無反射端より简 易無反射端の方が大きい值を示す。

（I）直管部

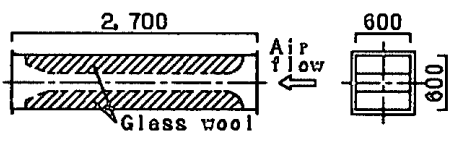

（II）曲管部

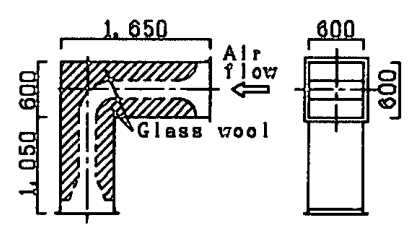

图 1 供試体

表 1 各無反射端の音圧反期係绕

\begin{tabular}{|c|c|c|c|c|c|}
\hline 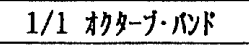 & 63 & \multicolumn{2}{|c|}{125} & 250 & 500 \\
\hline I S O無反射端 & 0.20 & \multicolumn{2}{|c|}{0.12} & 0.03 & 0.03 \\
\hline 简易無反射端 & 0.42 & \multicolumn{2}{|c|}{0.29} & 0.14 & 0.10 \\
\hline 1/3 オタターナ・ハト & 50 & 63 & 80 & 100 & $>125$ \\
\hline 最大音圧反的係败 & 0.4 & 0.35 & 0.3 & 0.25 & 0.15 \\
\hline
\end{tabular}

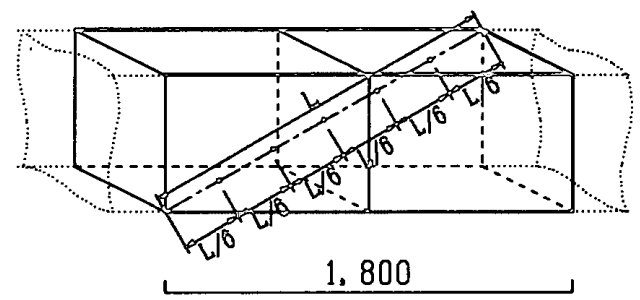

図2 マイクロホンの位置

\section{4、実㖵装膡および湘定方法}

本報では、無風時においてISOに規定されている固換

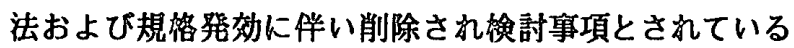
直接法を用いて測定を行なう。置換法ではISOに規定さ

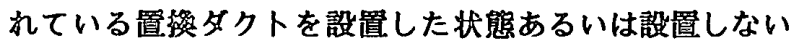
状態においてタクト内測定および残響室測定を行ない、 また、大がかりな設传の一つであるISO無反射端を設置 した状態においてダクト内湘定を行なう。直接法では、 IS0無反射端あるいは简易無反射端を設置し、いずれも 1/1オクターブ・バンドで測定を行なう。

なお、IS0 7235において規定されている湘定方法は全 て1/3オクターブ・バンドであるが、本報告では、騷音

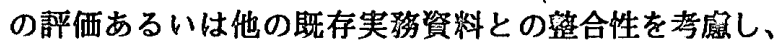
1/1オクターブ・バンドで測定を行ない、各測定方法に ついて㛟討を行なう。

\section{1 置換法}

実唤装置を図 3〜 6に示す。ダクト系(a)は消音器を 㨂入した状態、（b)は消音器をそれと同じ長さおよび畍 面の置換ダクトに置き换えた状態、(c)は何も捙入しな い状態とする。ただし、曲管部においてはダクト系(b) は行なっていない。各多クト系ともスピーカより1/1才 クターブ・バンドのピンク・ノイズを発生させる。ダク 卜内剆定は、叁ダクト系において消音器の下流側測定ダ クト内において、因 2 に示寸等間隔 5 ポイントの音圧レ

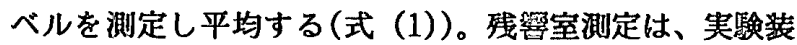
置图 4 および 6 に示すダクト開口端より放射された音の 残䈏室内音圧レベルを湘定し平均する。ダクト系 (a)と (b)または (c)との測定值の差をそれぞれ求め、それらを 挿入損失とする(式 (2))。なお、各ダク卜系ともスピー カへの入力奄圧を等しくしてある。
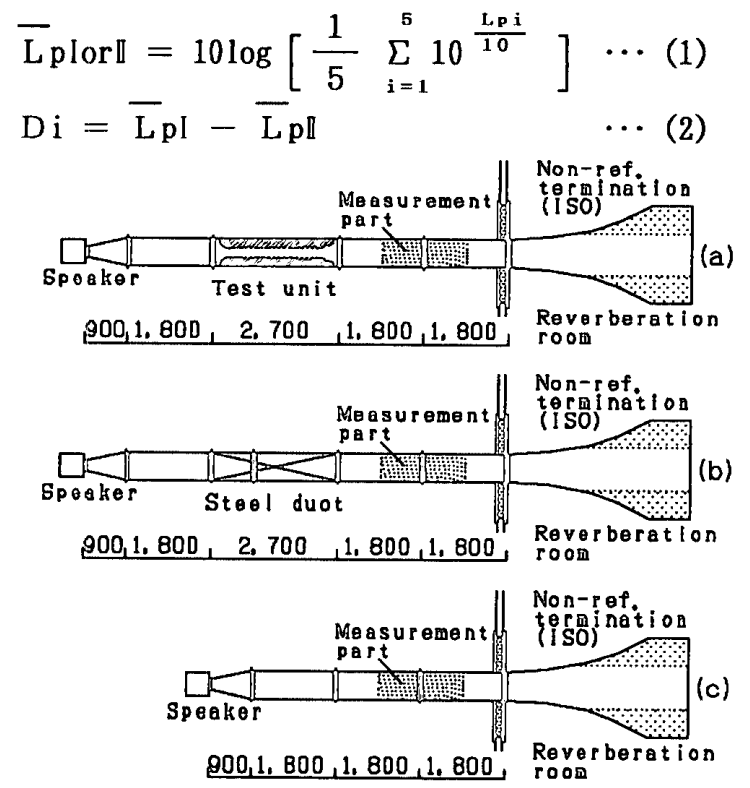

図 3 咨弱置（置換法・無反射端・直管部） 
L pi : 各测定点における音圧レベル $[\mathrm{dB}]$

L p I : ダクト系(b)または (c)における消音器下流側測 定ダクト内または残響室内平均音圧レベル [dB]

L $\mathrm{p} \llbracket$ ：ダクト系(a)における消音器下流側測定ダクト 内または残響室内平均音圧レベル $[\mathrm{dB}]$

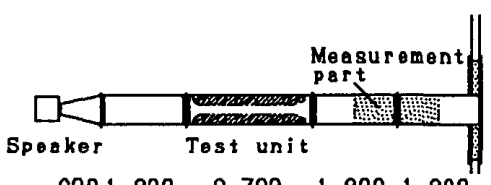

(a)

$900,1,800,2.700,1.800,1.800$, $200 \mathrm{~m}$

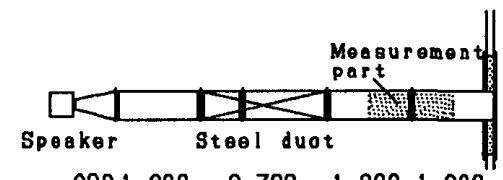

(b)

$000,1,800,2,700,1,800,1,800, \begin{gathered}\text { Roverberation } \\ \text { room }\end{gathered}$

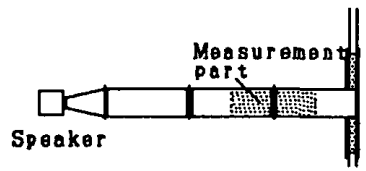

$800,1,800,1,800,1,800$ r $\begin{gathered}\text { Rever } \\ \text { room }\end{gathered}$

(c)

因 4 実唤装置（固換法・開口端・直管部）
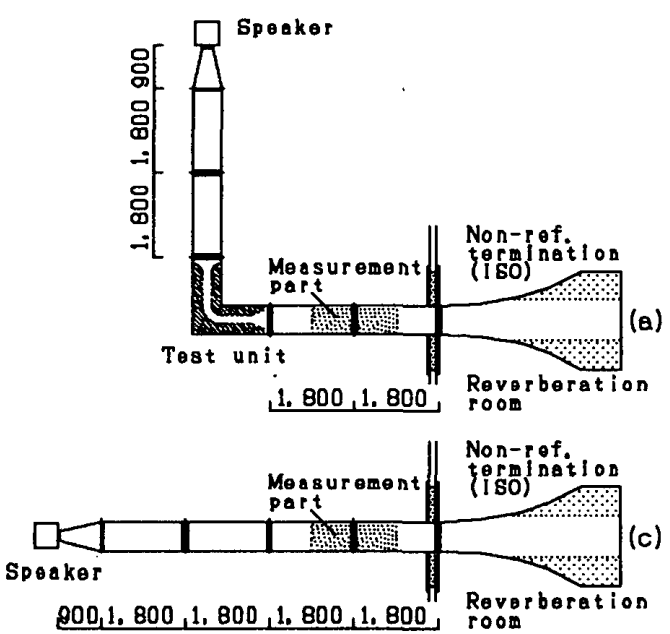

図 5 実験装置（置換法・無反射端・曲管部）
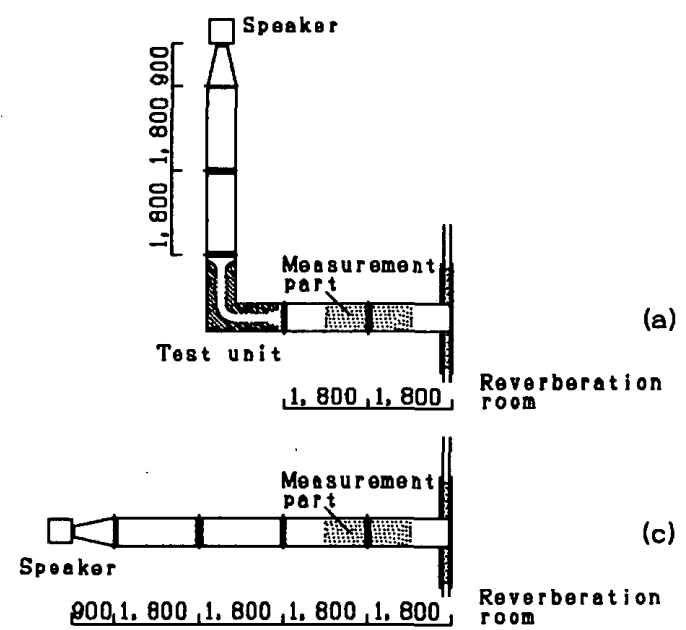

図6 実験置（置換法・開口端・曲管部）
D i : 括入損失 (Insertion loss) [dB]

\section{2 直接法}

実験装置を図 7 および 8 に示す。ダクト系(a)はISO無 反射端、（b)は簡易無反射端を端末に設置し、（c）は端末 に何も設置しない開口端とする。各ダクト系ともスピー カより $1 / 1$ オクターブ・バンドのピンク・ノイスを哭生 させる。各ダクト系の測定ダクト内において、図2に示 す等間隔 5 ポイントの音圧レベルを測定し平均する(式 (1))。消音器の上流および下流側断面とも同形のため、 上流側の測定ダクト内平均音圧レベルより下流側のそれ を減じて、その差を音響減衰とする(式 (3))。

$\mathrm{Dp}=\overline{\mathrm{L}} \mathrm{pl}-\overline{\mathrm{L}} \mathrm{pl}$

$\overline{\mathrm{L}} \mathrm{pI}$ : 消音器上流側測定ダクト内平均音圧レベル $[\mathrm{dB}]$ L pII : 消音器下流側湘定ダクト内平均音圧レベル $[\mathrm{dB}]$ $\mathrm{Dp}$ : 音圧レベル差

(Sound pressure level difference) [dB]

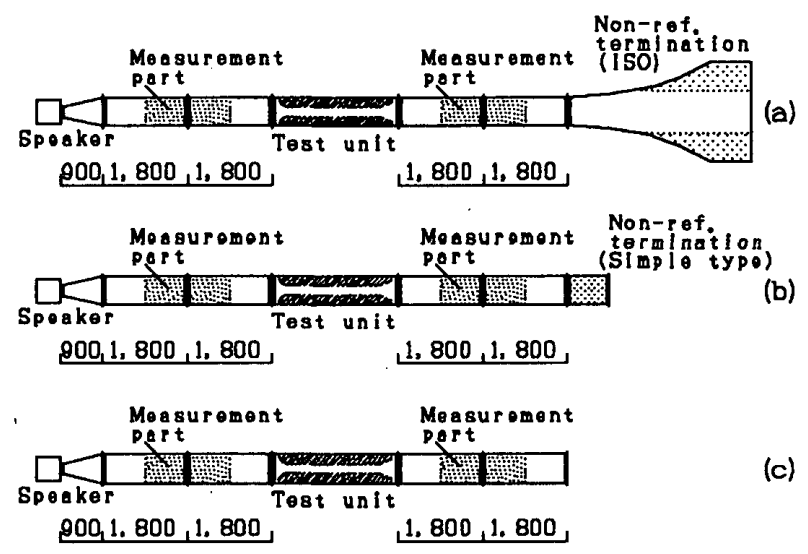

因 7 実駼監（直接法・直管部）

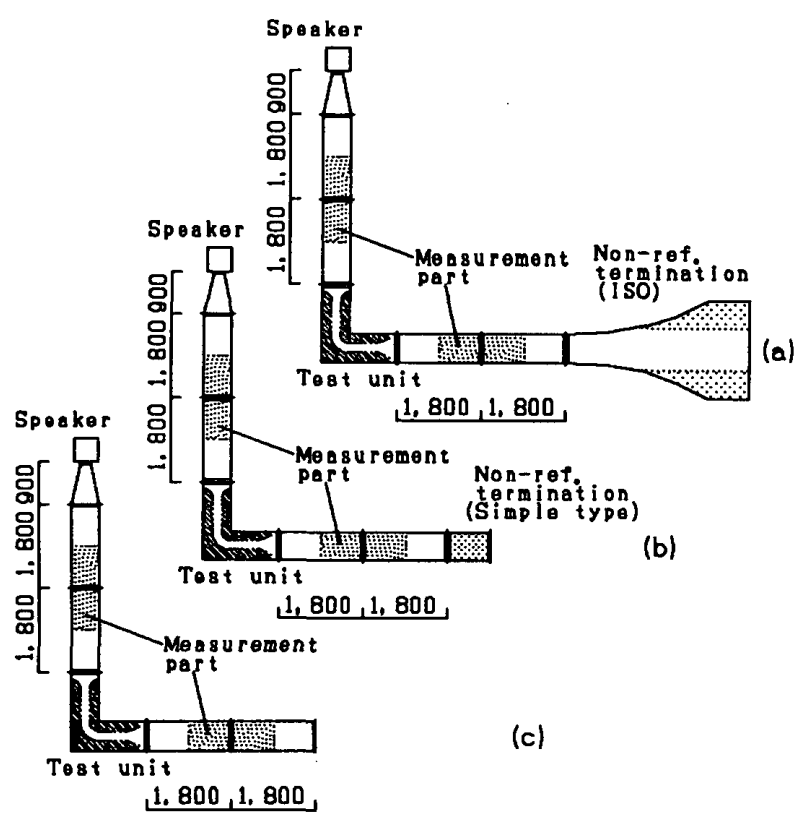

因 8 実験置（直接法・曲管部） 


\section{5。実験結果および考察}

\section{1 置換法における固換ダクトの必要性}

置換法による直管部の㨉入損失を图 9 および 10 に示 す。図中の (b)-(a)は置換ダクトを㨉入した状態、(c) 一(a)は何も挿入しない状態よりそれぞれ求めた挿入損 失を表わす。置換法における置換ダクトの有無による測 定值の差は一部3〜4dBを示すが、ダクト内および残㤱室 揤定いずれも全带域においてほほ同一の值を示す。この ことから、1/1オクターブ・バンドの剆定では、ダクト 内測定および残響室測定とも置抝ダクトの有無による測 定值への影繁はほとんどなく、置路タクトを設置しない 状態の測定でも十分であると考えられる。

\section{2 直換法におけるダクト内测定と残䇺室測定との} 比筑

置換法におけるダクト内測定と残管室測定の㨂入損失 の比铰を图 11 および 12 に示す。直管部の挿入損失は それぞれ置換ダクトを挿入しない忋態での值を示す。牫 蝆室測定は $125 \mathrm{~Hz}$ 帯域で他のものと比端して $5 \mathrm{~dB}$ 程度大き

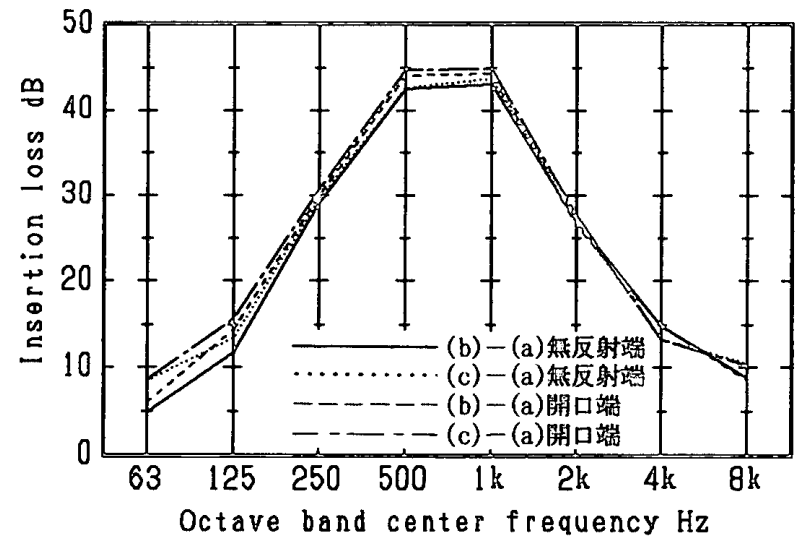

図 9 唒換法による直管部の扱入損失（ダクト内測定）

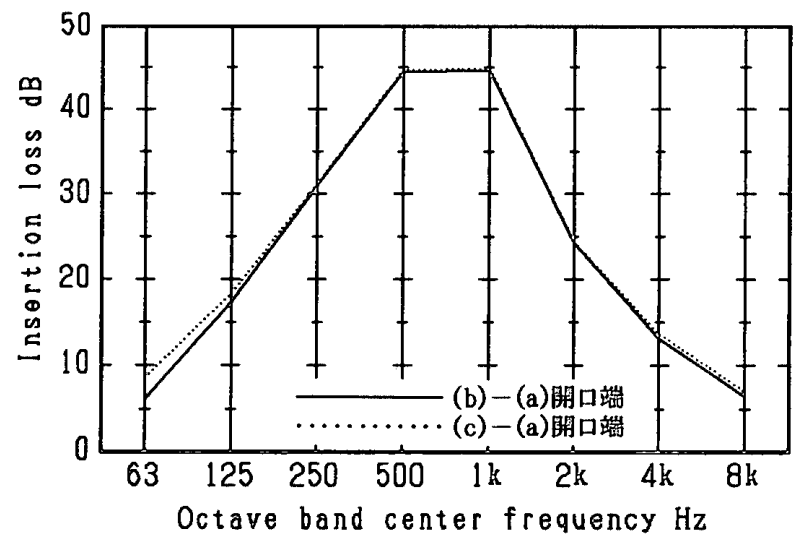

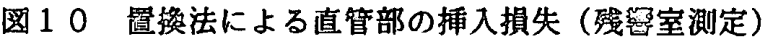

い値を示すが、他の周波数带域ではいずれもほぼ同様の 傾向を示す。ダクト内測定は無反射端の有然による大き な差はなく、全帯域においてほほ同一の值を示す。

\section{3 直接法における無反癿端の種頜および有烸によ

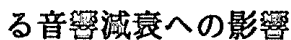

直接法による音響減衰を图13 および14 に示す。ISO

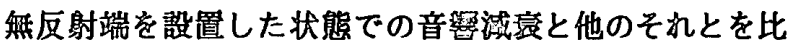
輘すると、直管部では $125 \mathrm{~Hz}$ 带域において简易無反射端 での湘定値が3dB程度小さいが、他の周波数帶域におい てはほほ同一の值を示す。曲管部では直管部に比べぼら つきがあり、250〜 4kHz带域において開口端での測定値 が2〜3dBの差を示す。全体的には直管部および曲管部い

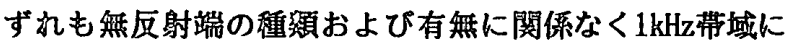
ピークを有する山形の傾向を示す。

このことから、直接法における $1 / 1$ オクターブ・バン ドの測定では、無反射端の種穎および有無による揤定值 への大きな影瑤はないと考えられる。

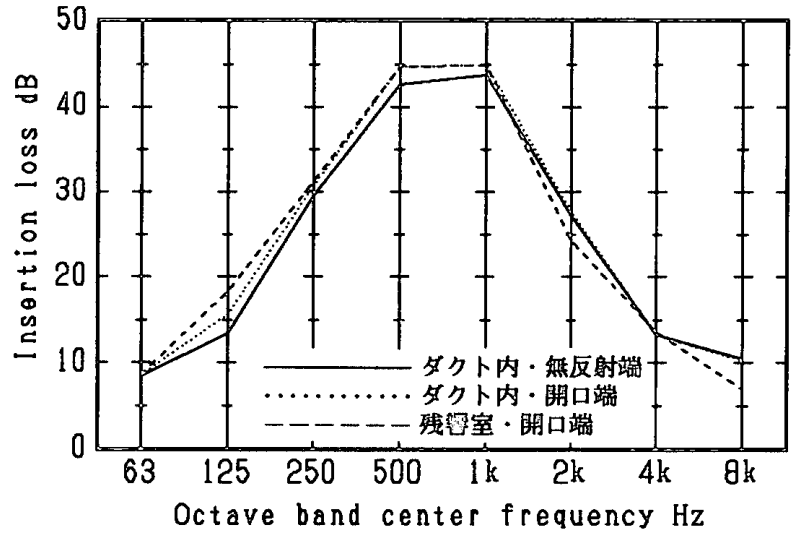

図 11 圂換法におけるダクト内測定と 牫習室测定との比（演管部）

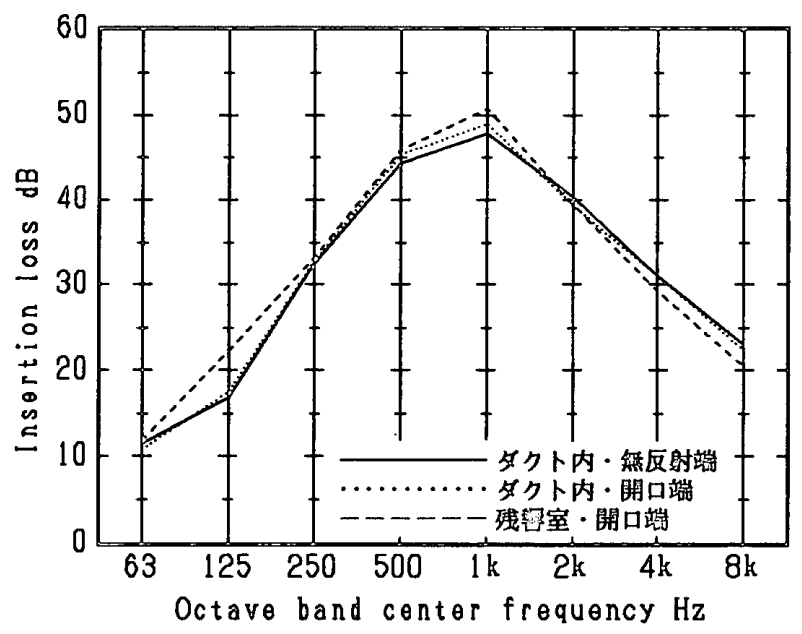

図 12 直換法におけるダクト内測定と

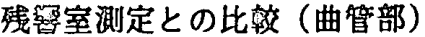


5. 4 直接法による音響減衰と置換法による㨉入損失 との比較

直接法による音響減衰（ISO無反射端設置時）と置換 法によるダクト内湘定（ISO無反射端設置時）および残 響室測定（開口端時）との比較を図 15 および 16 に示 す。直管部では、直接法と置換法によるダクト内測定と

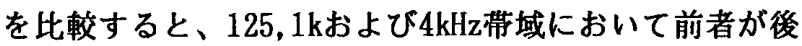
者より4〜 5dB大きな值を示し、また、直接法と置換法に よる残響室剆定とを比較すると、 $1 \mathrm{k} ， 4 \mathrm{k} よ ひ ゙ 8 \mathrm{kHz}$ 帯域 において前者が後者より $4 \mathrm{~dB}$ 程度大きな值を示す。曲管 部では、直接法と置換法によるダクト内測定とを比較す ると、 $500 \sim 2 \mathrm{kHz}$ 带域において前者が後者より3〜4dB程 度大きな值を示し、また、直接法と置換法による残響室 測定とを比較すると、 $125 \mathrm{~Hz}$ 带域においては後者の方が 前者より $3 \mathrm{~dB}$ 程度大きく、 $2 \mathrm{k} よ よ ゙ 8 \mathrm{kHz}$ 带域においては 前者が後者より4 5dB大きい值を示す。

このように、直接法と置換法とを比較すると、直管部 および曲管部とも中〜高音域において前者が後者よりも 大きな值を示し、大きいものでは $5 \mathrm{~dB}$ 程度の差を示す。

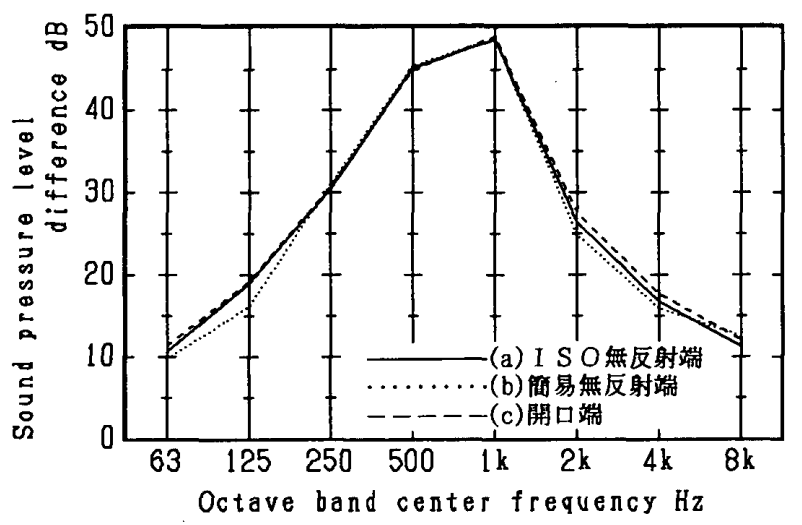

因 13 直接法による音箘隇衰（直管部）

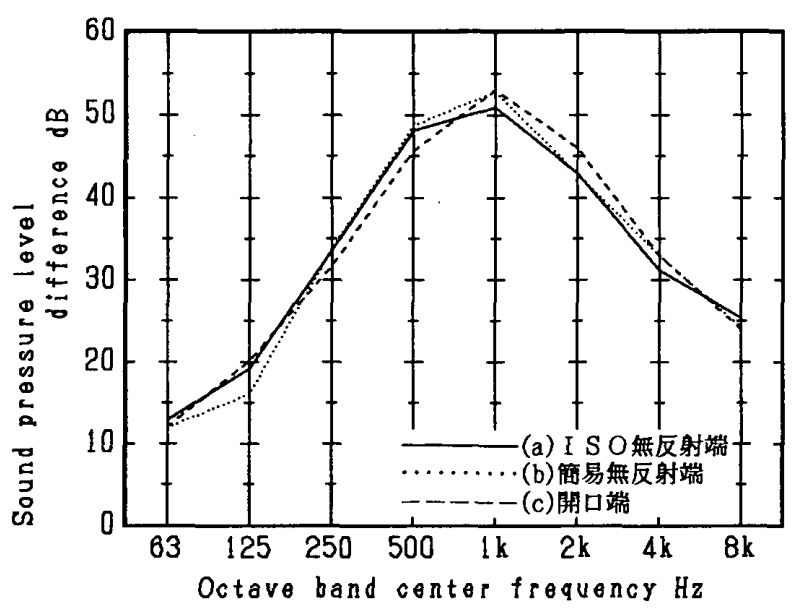

図14 直接法による音䈏減衰（曲管部）

\section{6. 結論}

$1 / 1$ オクターブ・バンドの測定における消音器の音響 減衰測定方法について、特徽を以下に示す。

1）置换法において直管部の挿入損失を得る場合、置換 ダクトの有無による测定值は、低音域において3〜 4dB 程度の差を示すが、他の周波数においてほほ同一の值 を示し、置換ダクトを設置しなくても、ほほ同様の結 果が得られる。

2) 直換法におけるダクト内測定では、タクト系端末 （ISO無反射端および開口端）の違いによる湘定值の 美は2dB以下であり、大がかりなISO無反射端を設置し なくてもほほ同様の結果が得られる。

3）直接法における無反射端の違い（ISO無反射端およ び簡易無反射端）および無反射端の有無による測定值 に大きな差はなく、簡易無反射端における測定でも十 分である。

4) 消音器の自由面積比が小さい場合、ダクト内で澌定 を行なう直接法および置換法におけるダクト内测定の 测定值と残響室法のそれとの差は、約5dBの範囲内で 一致すると考えられる。

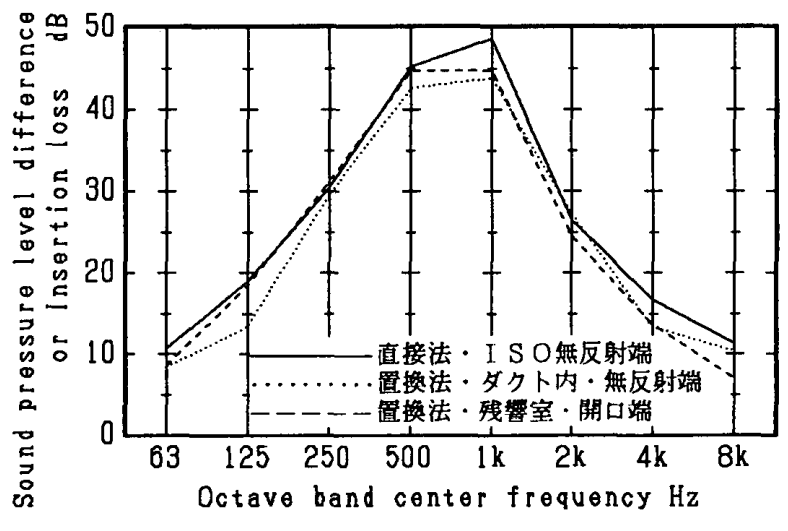

因 15 直接法による音響隇衰と 置換法による挿入損失との比較（直管部）

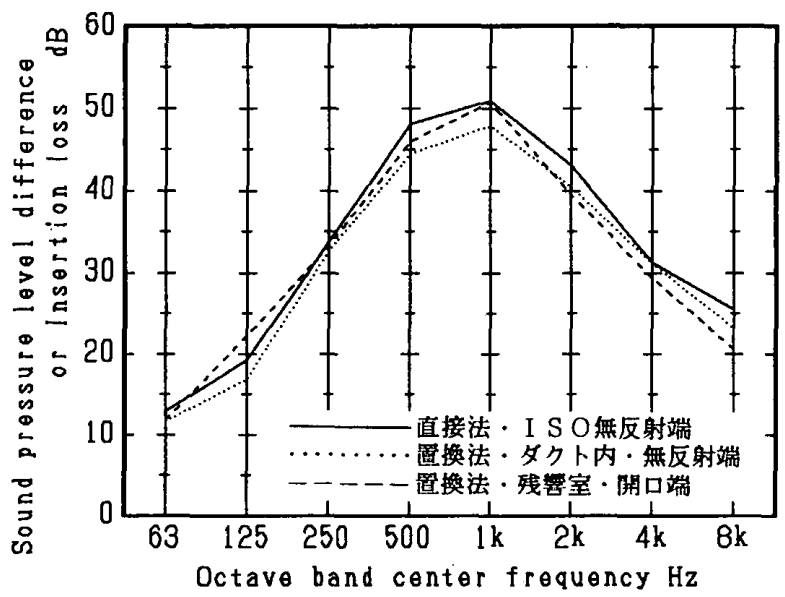

因 16 直接法による音響減衰と

置換法による㨉入揁失との比校（曲管部） 


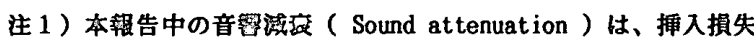
(Insertion loss) や直接法により求めた音仕レペル差（Sound pressure level difference) なとの用浯を包含する仏新の用緯と して用いる。また、これに伴い、面接法において求める供試体上

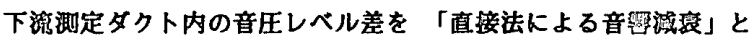
挐ぶこととする。

碳辞

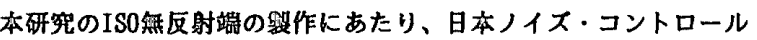
K.K.の飯岛和俊氏のこ劦力をいたたいた。きた、実䠯に祭しては、 当時日本大学の大学院生、卒論生諸君の労を多とした。ここに貶し て滋壾する。

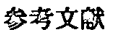

1) IS0 7235: Acoustics-Heasurement procedures for ducted silencers - Insertion loss, flow noise and total pressure loss

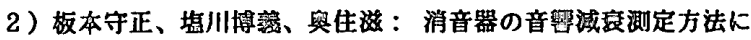

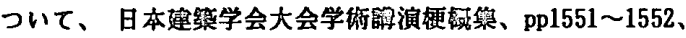
1994. 9 